\title{
Methylamine and Ammonium Transport Systems in Rhizobium leguminosarum MNF3841
}

\author{
By A. R. GLENN* AND M. J. DILWORTH \\ Nitrogen Fixation Research Group, School of Environmental and Life Sciences, Murdoch \\ University, Murdoch, Western Australia 6150, Australia
}

(Received 6 December 1983; revised 28 March 1984)

\begin{abstract}
As the sole source of nitrogen, methylamine supported the growth of a range of species of Rhizobium. The methylamine assimilatory system was inducible in $R$. leguminosarum MNF3841, whereas the capacity to utilize $\mathrm{NH}_{4}^{+}$as a nitrogen source was constitutive. An uptake system for $\left[{ }^{14} \mathrm{C}\right]$ methylamine (methylamine permease) was induced by growth of MNF3841 on methylamine or ethylamine. The uptake was sensitive to 2,4-dinitrophenol, azide and carbonyl cyanide $m$-chlorophenylhydrazone. The methylamine permease had a $K_{\mathrm{m}}$ of $0.035 \mathrm{mM}$, a $V_{\max }$ of $2.2 \mathrm{nmol} \mathrm{min}{ }^{-1}$ (mg protein) $)^{-1}$ and a $K_{\mathrm{i}}$ for ammonium of $1.5 \mathrm{~mm}$. Most of the $\left.{ }^{14} \mathrm{C}\right] \mathrm{methyl}-$ amine accumulated by cells was rapidly incorporated into TCA-insoluble materials. $\mathrm{An} \mathrm{NH}_{4}^{+}-$ sensitive methylamine-accumulating system distinct from the methylamine permease was demonstrated in ammonia-limited cells grown in continuous culture. This system, the ammonium permease, had a $K_{\mathrm{m}}$ of $0.11 \mathrm{~mm}$ (for methylamine), a $K_{\mathrm{i}}$ for $\mathrm{NH}_{4}^{+}$of $0.007 \mathrm{~mm}$ and a

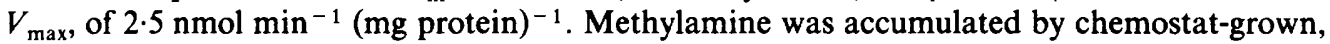
$\mathrm{N}$-limited cells and could exchange with unlabelled methylamine. Treatment with carbonyl cyanide $m$-chlorophenylhydrazone caused efflux of the accumulated methylamine, whereas high concentrations of $\mathrm{NH}_{4}^{+}$did not. Thus $R$. leguminosarum possesses a specific methylamine permease which is quite distinct from the ammonium permease.
\end{abstract}

\section{INTRODUCTION}

The mechanism of ammonia transport is of obvious importance to understanding the physiology of nitrogen fixation by Rhizobium, since both isolated bacteroids (Bergersen \& Turner, 1967) and cells induced for nitrogenase in the laboratory (O'Gara \& Shanmugam, 1976; Tubb, 1976; Bergersen \& Turner, 1978) liberate into the medium as ${ }^{15} \mathrm{NH}_{3}$ most of the ${ }^{15} \mathrm{~N}_{2}$ they fix.

Studies of ammonia transport mechanisms in bacteria have been approached in two major ways: the measurement of intracellular and extracellular ammonia concentrations (e.g. Dilworth \& Glenn, 1982), and the use of $\left[{ }^{14} \mathrm{C}\right]$ methylamine as an analogue for ammonium (Stevenson \& Silver, 1977).

In Azotobacter vinelandii, measurements of intra- and extracellular ammonia indicated that a 100-fold higher concentration existed inside the cells (Kleiner, 1975), but since cell suspensions were apparently toluenized prior to the measurements of intracellular ammonia, these data must be treated with caution. Similar concentration differences have been reported for Clostridium pasteurianum and Klebsiella pneumoniae (Kleiner \& Fitzke, 1979; Kleiner, 1982). By contrast, in Rhizobium leguminosarum grown on either histidine or $\mathrm{NH}_{4}^{+}$, no evidence was found for a gradient in ammonia concentration across the cell membrane (Dilworth \& Glenn, 1982).

While uptake of methylamine by eukaryotic cells appears to parallel uptake of $\mathrm{NH}_{4}^{+}$(Kleiner, 1981), the situation in prokaryotes is not as definitive. Since methylamine uptake on an ammonium carrier would be expected to be less efficient than ammonium uptake, the inhibition constant $\left(K_{\mathrm{i}}\right)$ for ammonium competition with methylamine would be expected to be lower than

Abbreviation: CCCP, carbonyl cyanide m-chlorophenylhydrazone. 
the Michaelis constant $\left(K_{\mathrm{m}}\right)$ for methylamine uptake (Kleiner, 1981). Data which conform to this prediction have been reported for A. vinelandii (Barnes \& Zimniak, 1981), C. pasteurianum (Kleiner \& Fitzke, 1981), K. pneumoniae (Kleiner, 1982), Azospirillum species (Hartmann \& Kleiner, 1982) and Rhodospirillum rubrum (Alef \& Kleiner, 1982). While the ideal situation for measuring methylamine uptake would require that no further metabolism of methylamine occurs, it is clear that for $\boldsymbol{A}$. vinelandii (Barnes \& Zimniak, 1981), C. pasteurianum (Kleiner \& Fitzke, 1981) and $K$. pneumoniae (Kleiner, 1982) methylamine is extensively metabolized to a less polar compound, probably $N^{5}$-methylglutamine $(\gamma$-glutamylmethylamide). However, methylamine does not serve as a nitrogen source for the growth of any of these bacteria.

In bacteria capable of using methylamine as a source of nitrogen for growth the situation appears to be different. In Pseudomonas species MA, growth with methylamine as a sole source of carbon and nitrogen results in the synthesis of a transport system of considerable capacity but high $K_{\mathrm{m}}$ (1 to $3 \mathrm{~mm}$ ), which is insensitive to ammonium inhibition (Bellion et al., 1980). When the same strain is grown on succinate with methylamine as the sole nitrogen source, a second transport system is induced which has a low $K_{\mathrm{m}}(0.016 \mathrm{mM})$ and relatively low capacity, and which shows weak competitive inhibition $\left(K_{\mathrm{i}}=4.8 \mathrm{mM}\right)$ by $\mathrm{NH}_{4}^{+}$(Bellion \& Weyland, 1982).

In bacteroids of $R$. leguminosarum loaded anaerobically with radioactive methylamine, Laane et al. (1980) showed that oxygen was necessary for methylamine export, and inferred that this applied to $\mathrm{NH}_{4}^{+}$movement also. Dilworth \& Glenn (1982) found that $\left[{ }^{14} \mathrm{C}\right]$ methylamine uptake into $R$. leguminosarum WU235 was an active process that was only slightly inhibited by a considerable molar excess of $\mathrm{NH}_{4}^{+}$, and suggested that uptake of methylamine was not necessarily a good index of ammonium uptake in this strain. In Rhizobium meliloti also, ammonium did not significantly inhibit methylamine uptake (Osburne, 1982), and efflux could not be demonstrated in response to ammonium additions (Wiegel \& Kleiner, 1982). By contrast, experiments with cowpea Rhizobium $32 \mathrm{H} 1$ showed that $\mathrm{NH}_{4}^{+}$did inhibit methylamine uptake at very low concentrations, and that counterflow of methylammonium and ammonium ions could occur (Gober \& Kashket, 1983). Extensive conversion of methylamine to a compound like $\mathrm{N}^{5}$ methylglutamine also occurred, but whether this strain could grow on methylamine was not apparent. Methylamine transport was not induced in aerobic cultures using glutamate as the nitrogen source, but was induced in the same medium under the microaerophilic growth conditions needed to induce nitrogenase (Gober \& Kashket, 1983). It is unclear how cowpea Rhizobium strains grow on low concentrations of $\mathrm{NH}_{4}^{+}$under aerobic conditions (Bergersen \& Turner, 1976) if a vital ammonium transport system cannot be synthesized.

It thus appears that where an organism is able to use methylamine as a nitrogen source for growth, methylamine uptake is likely to be via a specific inducible transport system that is unconnected with $\mathrm{NH}_{4}^{+}$transport.

In this paper we present evidence for the existence in $R$. leguminosarum MNF3841 of two permease systems which will transport methylamine. The first is induced only by growth on methylamine (or ethylamine) and we regard it as a methylamine permease. The second is derepressed only under nitrogen limitation (ammonia or nitrate), is very sensitive to inhibition by ammonium ions and appears to be an $\mathrm{NH}_{4}^{+}$permease.

\section{METHODS}

Organisms. The rhizobia used in this study are shown in Table 1.

Media. Strains were tested for growth on a solid medium containing the mineral salts used by Brown \& Dilworth (1975) with phosphate at $0.3 \mathrm{mM}$, mannitol $(10 \mathrm{mM})$ and nitrogen sources at $10 \mathrm{~mm}$. Rhizobium leguminosarum MNF3841 was grown in batch culture in liquid medium of the same composition supplemented with $40 \mathrm{mM}^{\text {- }}$ HEPES (pH 7.2).

Nodulation and preparation of bacteroids. Pea plants (Pisum sativum L. cv. Greenfeast) were nodulated by $R$. leguminosarum MNF3841 in pots and bacteroids isolated as described by Glenn et al., 1980): they were used immediately after isolation.

Continuous culture. The medium for continuous culture was similar to that for batch cultures, but contained $20 \mathrm{~mm}$-HEPES, pH 7-2. The carbon source was fructose or sucrose $(10 \mathrm{~mm})$. Cells were cultured under $\mathrm{NH}_{4}^{+}-$

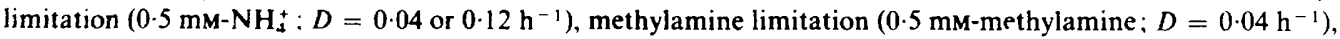


Table 1. Rhizobium strains used

Fast-growing rhizobia

R. leguminosarum WU235

R. leguminosarum MNF3841

R. trifolii TAl

Cowpea Rhizobium NGR234

Slow-growing rhizobia

Cowpea Rhizobium 32H1

Cowpea Rhizobium CB756

Rhizobium japonicum WU40

Rhizobium lupini WU8
Source

Institute of Agriculture, University of Western Australia, Australia

Str ${ }^{r}$ derivative of strain 300 of Johnston \& Beringer (1975)

Dr D. L. Chatel, W. Australian Department of Agriculture, Australia Dr M. J. Trinick, CSIRO, Canberra, Australia

\section{Source}

Dr J. Burton, Nitragin Co., USA

Dr R. A. Date, CSIRO, Brisbane, Australia

Institute of Agriculture, University of Western Australia, Australia

phosphate limitation $\left(0.05 \mathrm{~mm} ; D=0.12 \mathrm{~h}^{-1}\right)$ or under $\mathrm{O}_{2}$ limitation $\left(D=0.092 \mathrm{~h}^{-1}\right)$. The chemostats had working volumes of $75 \mathrm{ml}$ and were operated at $28^{\circ} \mathrm{C}$.

Uptake experiments. Cells were prepared for uptake measurements as described by Dilworth \& Glenn (1982) except that they were centrifuged and washed rather than Millipore-filtered. Competitors or inhibitors were added $60 \mathrm{~s}$ prior to the addition of $0 \cdot 1 \mathrm{mM}-\left[{ }^{14} \mathrm{C}\right]$ methylamine, and samples were taken at intervals (up to $10 \mathrm{~min}$ ), filtered and washed with $10 \mathrm{ml}$ minimal salts solution; radioactivity on the filter was measured by liquid scintillation counting (Hudman \& Glenn, 1980). [ $\left.{ }^{14} \mathrm{C}\right]$ Methylamine hydrochloride (specific activity $43.3 \mathrm{mCi} \mathrm{mmol}^{-1}$; 1.6 GBq $\mathrm{mmol}^{-1}$ ) was from New England Nuclear.

Incorporation experiments. Cells of MNF3841 were grown at $28^{\circ} \mathrm{C}$ in mannitol-methylamine to a cell density of $0.11 \mathrm{mg} \mathrm{dry} \mathrm{wt} \mathrm{ml}^{-1}$, centrifuged, washed twice and resuspended at a cell density of approximately $0.175 \mathrm{mg}$ dry wt $\mathrm{ml}^{-1}$ in minimal salts-mannitol containing $0.4 \mathrm{mM}-\left[{ }^{14} \mathrm{C}\right]$ methylamine $(0.2 \mu \mathrm{Ci})$. Samples $(0.5 \mathrm{ml})$ were taken at intervals into cold $5 \%(\mathrm{w} / \mathrm{v}) \mathrm{TCA}$ containing $0.05 \%$ methylamine, stored for $30 \mathrm{~min}$, filtered and washed twice with the same solution.

Growth experiments. Cells of strain MNF3841 were grown on minimal salts medium containing mannitol $(10 \mathrm{mM})$ plus either methylamine or $\mathrm{NH}_{4}^{+}$or nitrate $(10 \mathrm{~mm})$ to a cell density of approximately $0.31 \mathrm{mg}$ dry wt $\mathrm{ml}^{-1}$, centrifuged, washed with minimal salts solution, and resuspended in a similar medium containing the appropriate nitrogen source at $10 \mathrm{~mm}$.

Analytical methods. Ammonia was measured by the phenol-hypochlorite method of Fawcett \& Scott (1960) and methylamine by a modification of the ninhydrin method of Spies (1957), with a heating time of $20 \mathrm{~min}$ at $100^{\circ} \mathrm{C}$ for colour development. Bacterial protein was measured by the Lowry method with bovine serum albumin as the standard.

\section{RESULTS}

Growth of rhizobial strains on methylamine. All fast-growing strains of Rhizobium (R. leguminosarum WU235 and MNF3841, Rhizobium trifolii TA1 and cowpea Rhizobium NGR 234) grew on solid media with methylamine as the sole source of nitrogen. Slow-growing strains (Rhizobium lupini WU8, Rhizobium japonicum WU40 and cowpea Rhizobium CB756 and 32H1) also grew, $R$. lupini being the slowest.

Growth of MNF3841 on methylamine as a nitrogen source. Cells grown in mannitol-methylamine to a cell density of approximately $0.23 \mathrm{mg} \mathrm{dry} \mathrm{wt} \mathrm{ml}^{-1}$ and resuspended in the same medium grew immediately with a mean generation time of $10.3 \mathrm{~h}$. Cells grown and resuspended in mannitol- $\mathrm{NH}_{4}^{+}$grew immediately with a generation time of $3.5 \mathrm{~h}$. Methylamine-grown cells transferred to mannitol- $\mathrm{NH}_{4}^{+}$also grew immediately with a low generation time $(3.5 \mathrm{~h})$.

Cells grown in mannitol- $\mathrm{NH}_{4}^{+}$and transferred to mannitol-methylamine showed a limited increase in turbidity for $2 \mathrm{~h}$ after which growth ceased. After $5 \mathrm{~h}$ the cells began to grow with a mean generation time of $9.9 \mathrm{~h}$, a rate virtually identical to that observed previously for cells growing on methylamine as a nitrogen source.

Cells of strain MNF3841 grown on a mannitol-minimal salts medium containing nitrate $(10 \mathrm{mM})$ as the nitrogen source grew with a mean generation time of $4.5 \mathrm{~h}$ when resuspended in a similar medium. Nitrate-grown cells resuspended in mannitol- $\mathrm{NH}_{4}^{+}$media grew immediately with a generation time of $3.5 \mathrm{~h}$, providing additional evidence that cells grown on nitrogen sources other than $\mathrm{NH}_{4}^{+}$are able to grow immediately when transferred to it. 
Substrate consumption rates. During growth experiments similar to those described, samples of supernatant were taken to measure the utilization rates for $\mathrm{NH}_{4}^{+}$and methylamine. Ammonium- or methylamine-grown cells of MNF3841 consumed $\mathrm{NH}_{4}^{+}$at $2 \cdot 1$ and $1.8 \mu \mathrm{mol} \mathrm{h}^{-1}$ (mg dry wt $)^{-1}$, respectively, and there was no change in the rate of utilization with time. Methylamine-grown cells when resuspended in fresh methylamine medium utilized methylamine at $0.5 \mu \mathrm{mol} \mathrm{h}^{-1}(\mathrm{mg} \text { dry } \mathrm{wt})^{-1}$. When ammonium-grown cells were resuspended in methylaminecontaining medium they did not utilize any methylamine for $5 \mathrm{~h}$ and thereafter consumed it at a rate of $0.6 \mu \mathrm{mol} \mathrm{h}^{-1}$ (mg dry wt) ${ }^{-1}$.

These growth data provided clear evidence that the methylamine utilization system in $R$. leguminosarum MNF3841 was inducible and that it was clearly different from the $\mathrm{NH}_{4}^{+}$consuming system.

The methylamine uptake system. Cells of $R$. leguminosarum MNF3841 were grown on a variety of nitrogen sources, and their rate of $\left[{ }^{14} \mathrm{C}\right]$ methylamine uptake was examined after they had been centrifuged and washed. Cells grown on methylamine and ethylamine as the sole nitrogen source were able to take up $\left[{ }^{14} \mathrm{C}\right]$ methylamine $\left[1.5\right.$ and $1.09 \mathrm{nmol} \mathrm{min}{ }^{-1}(\mathrm{mg} \text { protein })^{-1}$, respectively] but cells grown on nitrate, glutamate or $\mathrm{NH}_{4}^{+}$had only low levels of uptake [0.01, 0.03 and $0.08 \mathrm{nmol} \mathrm{min}^{-1}(\mathrm{mg} \text { protein })^{-1}$, respectively]. These data were consistent with the induction of the methylamine permease before methylamine could be utilized as a nitrogen source of rhizobial growth.

The addition of carbonyl cyanide $m$-chlorophenylhydrazone (CCCP; $0.025 \mathrm{~mm}$ ) or 2,4dinitrophenol $(0.5 \mathrm{mM})$ or azide $(1 \mathrm{mM})$ inhibited uptake of $\left[{ }^{14} \mathrm{C}\right]$ methylamine by more than $95 \%$. The process thus appeared to be active and dependent on an energized membrane, though these conclusions are limited by the possible effects of further metabolism of methylamine.

Kinetic data. The apparent $K_{\mathrm{m}}$ for the methylamine permease was determined on five occasions over the concentration range 0.01 to $0.15 \mathrm{mM}$ and the following values were obtained: Lineweaver-Burk plot, 0.035 mM (SD, 0.010); Hans-Woolf, 0.050 mM (SD, 0.012); and nonlinear regression (Duggleby, 1981), $0.03 \mathrm{~mm}$. The $V_{\max }$ was $2.2 \mathrm{nmol} \mathrm{min}^{-1}(\mathrm{mg} \text { protein) })^{-1}$.

The effect of ammonium and amines on methylamine transport. The capacity of cells grown on methylamine as sole $\mathrm{N}$ source to accumulate $\left[{ }^{14} \mathrm{C}\right]$ methylamine in the presence of $\mathrm{NH}_{4}^{+}$and amines was investigated. The accumulation of methylamine by adapted cells of MNF3841 was found to be relatively insensitive to $\mathrm{NH}_{4}^{+}$. Ammonium was a poor competitive inhibitor with a $K_{\mathrm{i}}$ of $1.5 \mathrm{mM}$. Ethylamine was a more potent inhibitor of methylamine transport with a $K_{\mathrm{i}}$ of $0.5 \mathrm{~mm}$. Propylamine was also a poor inhibitor of methylamine transport with a $K_{\mathrm{i}}$ of $2.6 \mathrm{~mm}$. Glycine appeared to have no significant effect on methylamine uptake even when present in a 100 -fold excess. In the presence of $1 \mathrm{mM}-\mathrm{NH}_{4}^{+}$the apparent $K_{\mathrm{m}}$ for methylamine uptake was $0 \cdot 118 \mathrm{~mm}$.

Methylamine transport in $\mathrm{NH}_{4}^{+}$-grown cells. Ammonium-grown cells of MNF3841 have a low, but measurable, rate of $\left[{ }^{14} \mathrm{C}\right]$ methylamine transport $\left[0.08 \mathrm{nmol} \mathrm{min}{ }^{-1}\right.$ (mg protein) $\left.{ }^{-1}\right]$. To determine if this represented a basal level of the methylamine permease, or if transport involved another, separate uptake system, the $K_{\mathrm{i}}$ values for $\mathrm{NH}_{4}^{+}$, ethylamine and propylamine were determined. The $K_{\mathrm{i}}$ values were $0.55 \mathrm{mM}$ for ethylamine, $1.2 \mathrm{mM}$ for $\mathrm{NH}_{4}^{+}$and $2.6 \mathrm{mM}$ for propylamine, values which are essentially the same as those obtained for methylamine-grown cells. It appeared therefore that the low rate of methylamine transport observed in $\mathrm{NH}_{4}^{+}$-grown cells was due to a basal level of the methylamine permease, not an $\mathrm{NH}_{4}^{+}$permease.

Efflux experiments with the methylamine permease. Cells grown in batch culture on mannitolmethylamine were loaded with $\left[{ }^{14} \mathrm{C}\right]$ methylamine and then treated with methylamine $(25 \mathrm{mM})$ or $\mathrm{NH}_{4}^{+}(25 \mathrm{mM})$ or CCCP $(0.02 \mathrm{mM})$ or azide $(1 \mathrm{mM})$. None of these treatments resulted in a loss of radioactivity from the cells.

Incorporation into TCA-insoluble material was therefore measured as a fraction of the total accumulated label as described in Methods. Samples $(0.1 \mathrm{ml})$ were also filtered to measure the rate of accumulation of label. About $85 \%$ of the radioactivity was incorporated into TCAinsoluble material, thus explaining the lack of efflux described earlier. 
Chemostat culture studies. Cells from chemostat cultures of MNF3841 grown under a variety of limitations were examined for their capacity to transport $\left[{ }^{14} \mathrm{C}\right]$ methylamine. Methylaminelimited cells transported methylamine via a system which was relatively insensitive to $\mathrm{NH}_{4}^{+}$ (Table 2). The $K_{\mathrm{i}}$ (for $\mathrm{NH}_{4}^{+}$) for this system was $1.25 \mathrm{mM}$ and the $K_{\mathrm{m}} 0.050 \mathrm{mM}$ (Hans-Woolf), indicative of the methylamine permease described for batch cultures. Phosphate-limited cells and oxygen-limited cells showed only a basal activity of the methylamine permease (Table 2).

Cells growing on $0.5 \mathrm{mM}-\mathrm{NH}_{4}^{+}$were ammonia-limited; the effluent $\mathrm{NH}_{4}^{+}$concentration was $0.016 \mathrm{mM}$. Increasing the $\mathrm{NH}_{4}^{+}$concentration to $1 \mathrm{mM}$ resulted in a doubling of the cell density from 0.19 to $0.38 \mathrm{mg}$ dry wt ml ${ }^{-1}$. Such cells showed a $\left[{ }^{14} \mathrm{C}\right]$ methylamine uptake activity which was clearly sensitive to $\mathrm{NH}_{4}^{+}$inhibition (Table 2). Cells from nitrate-limited chemostats also showed $\mathrm{NH}_{4}^{+}$-sensitive $\left[{ }^{14} \mathrm{C}\right]$ methylamine uptake.

Kinetics of the ammonium permease. $\left[{ }^{14} \mathrm{C}\right]$ methylamine uptake in $\mathrm{NH}_{4}^{+}$-limited cells of MNF3841 was investigated in more detail - particularly the effect of substrate concentration and the effect of $\mathrm{NH}_{4}^{+}$. The $K_{\mathrm{m}}$ values quoted are the means of four separate determinations and the sDS were less than $0.015 \mathrm{mM}$. The $K_{\mathrm{m}}$ determined over the range 0.010 to $0.150 \mathrm{~mm}$ was $0.117 \mathrm{mM}$ (Lineweaver-Burk) or $0.11 \mathrm{mM}$ (Hans-Woolf) with a $V_{\max }$ of $2.5 \mathrm{nmol} \mathrm{min}$ - $^{-1}$ (mg protein $)^{-1}$. Over the range $0.005-0.15 \mathrm{mM}, \mathrm{NH}_{4}^{+}$was a powerful competitive inhibitor $\left(K_{\mathrm{i}}\right.$ $0.007 \mathrm{mM}$; Fig. 1). When the kinetic characteristics of this system were compared with those for the methylamine permease, it was clear that the apparent $K_{\mathrm{m}}$ values for methylamine varied only two- to threefold, while the $\mathrm{NH}_{4}^{+}$sensitivity of the two systems was vastly different. Because the $\mathrm{NH}_{4}^{+}$-sensitive system found in cells growing under inorganic $\mathrm{N}$ limitation has the characteristics predicted for $\mathrm{NH}_{4}^{+}$transport we are terming it a rhizobial ammonium permease.

Table 2. Rates of $\left[{ }^{14} \mathrm{C}\right]$ methylamine uptake in the presence and absence of $1 \mathrm{mM}^{-} \mathrm{NH}_{4}^{+}$by $R$. leguminosarum MNF3841 grown under various limitations

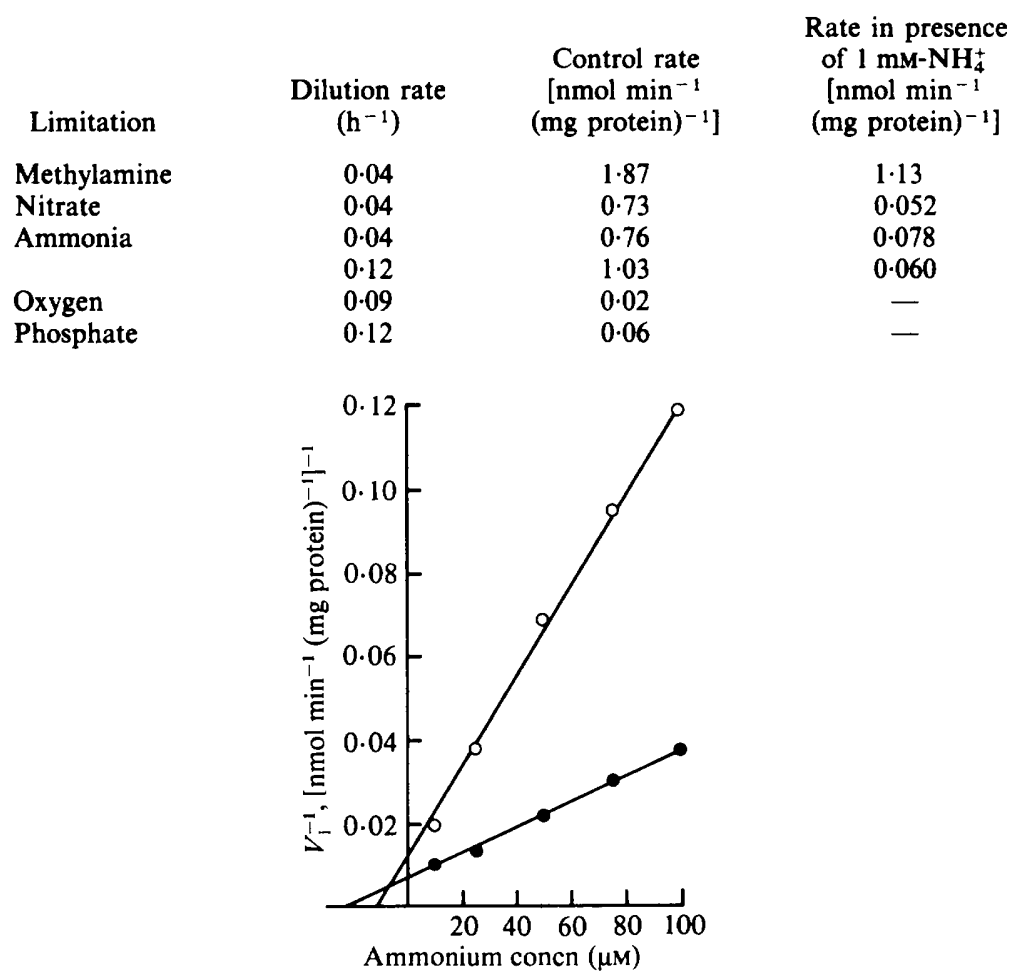

Fig. 1. Dixon plot showing the effect of $\mathrm{NH}_{4}^{+}$on the uptake of $\left[{ }^{14} \mathrm{C}\right]$ methylamine by $\mathrm{NH}_{4}^{+}$-limited chemostat cells of $\boldsymbol{R}$. leguminosarum MNF3841. Methylamine concentration was $0.02 \mathrm{mM}(\mathrm{O})$ or $0.1 \mathrm{mM}(\mathrm{O})$. 


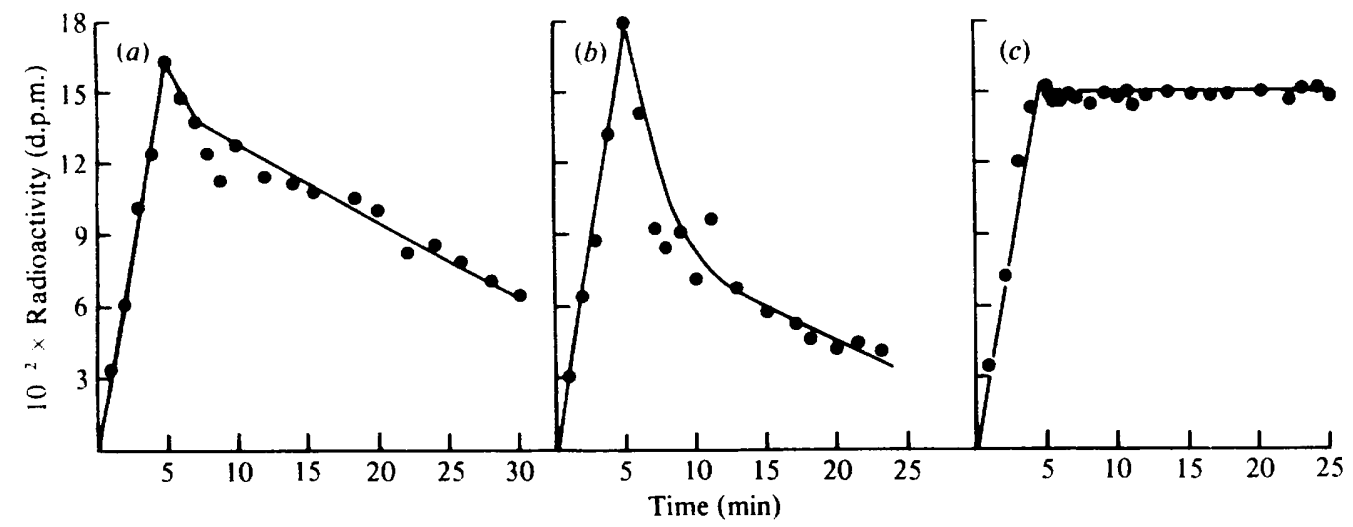

Fig. 2. The effect of methylamine, CCCP or $\mathrm{NH}_{4}^{+}$on the retention of accumulated $\left[{ }^{14} \mathrm{C}\right]$ methylamine by $\mathrm{NH}_{4}^{+}$-limited chemostat-grown cells of $R$. leguminosarum MNF3841. Cells were allowed to take up $\left[{ }^{1+} \mathrm{C}\right]$ methylamine for $5 \mathrm{~min}$, after which time (a) $25 \mathrm{~mm}$-methylamine, (b) $0.02 \mathrm{mM}-\mathrm{CCCP}$, or $(c)$ $25 \mathrm{mM}-\mathrm{NH}_{4} \mathrm{Cl}$ was added to the cells.

Characteristics of the rhizobial ammonium permease. Cells from ammonia-limited chemostats were unable to accumulate $\left[{ }^{14} \mathrm{C}\right]$ methylamine when treated with $\mathrm{CCCP}(0.02 \mathrm{mM})$, azide $(1 \mathrm{mM})$ or 2,4-dinitrophenol $(1 \mathrm{mM})$. Like the methylamine permease this system was probably active and dependent on an energized membrane.

Efflux of radioactive $\left[{ }^{14} \mathrm{C}\right]$ methylamine from $\mathrm{NH}_{4}^{+}$-limited cells. The efflux of $\left[{ }^{14} \mathrm{C}\right]$ methylamine from $\mathrm{NH}_{4}^{+}$-limited cells was followed after they were allowed to accumulate label for $5 \mathrm{~min}$ and then treated with $25 \mathrm{~mm}$ (final concentration) methylamine. Samples taken over the next $25 \mathrm{~min}$ showed clear evidence for efflux of label when there was a large external concentration of methylamine (Fig. 2a). The half-time for the exchange was about $25 \mathrm{~min}$. This was clearly different from the methylamine-grown cells which rapidly incoporated most of the radioactivity into TCA-precipitable material. When a similar experiment was carried out on cells accumulating $\left[{ }^{14} \mathrm{C}\right]$ methylamine by treating them with CCCP $(0.02 \mathrm{mM})$, a clear loss of label from the cells occurred (Fig. $2 b$ ), a result again quite distinct from that with methylamine-grown cells.

It might be considered that $\mathrm{NH}_{4}^{+}$itself should induce an efflux of $\left[{ }^{14} \mathrm{C}\right]$ methylamine from cells of $R$. leguminosarum MNF3841. However, there was no $\mathrm{NH}_{4}^{+}$-induced efflux of intracellular $\left[{ }^{14} \mathrm{C}\right]$ methylamine (Fig. $2 c$ ). This result is in accord with our previous work (Dilworth \& Glenn, 1982), which showed that relatively high concentrations of ammonia (at least greater than $2.5 \mathrm{~mm}$ ) rapidly equilibrate across the rhizobial membrane. Under these conditions, there will be a high concentration $(25 \mathrm{~mm})$ of ammonia inside the cells within $1.5 \mathrm{~min}$ which will effectively prevent label from leaving.

The data presented provide clear evidence that in laboratory-grown cultures of $R$. leguminosarum there are two separate and distinct permeases capable of transporting methylamine. One of these is the true methylamine permease induced by growth on methylamine; the other has the characteristics of an $\mathbf{N H}_{4}^{+}$permease and is produced only when the cells are grown under inorganic nitrogen limitation.

Methylamine transport in isolated bacteroids. Pea bacteroids accumulated $\left[{ }^{14} \mathrm{C}\right]$ methylamine only very slowly $\left[0.024 \mathrm{nmol} \mathrm{min} \mathrm{m}^{-1}(\mathrm{mg} \text { protein })^{-1}\right]$. This uptake was relatively insensitive to inhibition by $1 \mathrm{mM}^{-\mathrm{NH}_{4}^{+}}\left[0.017 \mathrm{nmol} \mathrm{\textrm {min } ^ { - 1 }}\left(\mathrm{mg}\right.\right.$ protein) $\left.{ }^{-1}\right]$. Control experiments showed that these bacteroids were able to accumulate $\left[{ }^{14} \mathrm{C}\right]$ succinate, but unable to take up fructose, a pattern described previously for this strain (Glenn et al., 1980; Glenn et al., 1984). The rates and ammonia insensitivity of the accumulation of $\left[{ }^{14} \mathrm{C}\right]$ methylamine by bacteroids suggest that this material was accumulated by a basal level of the methylamine permease and not via the ammonium permease. 


\section{DISCUSSION}

The results presented suggest that $R$. leguminosarum MNF3841 resembles Pseudomonas species MA (Bellion et al., 1980; Bellion \& Weyland, 1982) in its ability to synthesize a methylamine permease with methylamine as a nitrogen source for growth. Thus, the apparent $K_{\mathrm{m}}$ values for methylamine and the degree of inhibition by $\mathrm{NH}_{4}^{+}$are low, and the permeases are induced by growth on alkylamines rather than by $\mathrm{NH}_{4}^{+}$. Induction of the transport system apparently parallels induction of the necessary enzymes for methylamine metabolism, and leads to extensive incorporation of methylamine carbon into cells of MNF3841.

Cells of MNF3841 grown on high (10 mM) concentrations of nitrogen sources other than methylamine also transport methylamine to a limited extent, and for ammonia-grown cells the system responsible has the same properties as that induced by methylamine. Accordingly, under most conditions used for growth of Rhizobium in the laboratory, measurement of methylamine transport is likely to represent repressed levels of a methylamine permease relatively insensitive to inhibition by $\mathrm{NH}_{4}^{+}$. Such appears to be the case for $R$. meliloti (Osburne, 1982). If the other enzymes of methylamine utilization are induced to roughly the same extent as the permease, efflux of radioactive methylamine would not be expected, a result noted by Wiegel \& Kleiner (1982) for R. meliloti.

Since the low level of $\left[{ }^{14} \mathrm{C}\right]$ methylamine uptake by pea bacteroids has the characteristics of the methylamine permease rather than the ammonium permease, it is probable that the bacteroid environment is non-limiting with respect to nitrogen. It is also probable that active methylamine export by bacteroids (Laane et al., 1980) will involve repressed levels of the methylamine permease and be unreliable as an index of ammonia export.

Growth of MNF3841 in a chemostat on limiting ammonia or nitrate results in a methylamine uptake activity with entirely different kinetic parameters. This system is inhibited by low concentrations of $\mathrm{NH}_{4}^{+}$, as are the methylamine transport activities of $A$. vinelandii (Barnes \& Zimniak, 1981), C. pasteurianum (Kleiner \& Fitzke, 1981), K. pneumoniae (Kleiner, 1982), Azospirillum spp. (Hartmann \& Kleiner, 1982) and $R$. rubrum (Alef \& Kleiner, 1982), none of which is able to use methylamine as a source of nitrogen for growth. Unlike $R$. leguminosarum, these other organisms appear to be able to synthesize an $\mathrm{NH}_{4}^{+}$permease under conditions where nitrogen is not limiting. In $R$. leguminosarum, however, nitrogen-excess conditions appear to lead to repressed levels of a methylamine permease rather than an $\mathrm{NH}_{4}^{+}$permease.

The situation in the cowpea Rhizobium (Bradyrhizobium) 32H1 is somewhat confusing. Methylamine transport in this strain is mediated by a system with a low $K_{\mathrm{m}}$ for methylamine and is inhibited by low concentrations of $\mathrm{NH}_{4}^{+}$(Gober \& Kashket, 1983). Methylamine taken up can efflux, though not necessarily as methylamine, and the general picture would seem to be one of an organism unable to use methylamine for growth. However, we find that this strain grows on plates with methylamine as the sole source of nitrogen, albeit slowly. Another unusual finding is that only under microaerophilic conditions does strain $32 \mathrm{H} 1$ produce the methylaminetransporting $\left(\mathrm{NH}_{4}^{+}\right.$permease) system (Gober \& Kashket, 1983), yet it can grow under aerobic conditions with $\mathrm{NH}_{4}^{+}$as the nitrogen source (Bergersen \& Turner, 1976). The apparent inconsistency may be resolved if $32 \mathrm{Hl}$ also produces the $\mathrm{NH}_{4}^{+}$permease system at low nitrogen concentrations, but relies on a diffusive mechanism for ammonia uptake at higher concentrations, as suggested for $R$. leguminosarum by Dilworth \& Glenn (1982).

Further study of ammonium transport in fast-growing rhizobia such as $R$. leguminosarum will need to use ammonia- or nitrate-limited chemostats to separate the ammonium permease from the methylamine permease, as well as mutants completely lacking the methylamine permease system to allow the ammonium permease to be studied directly.

We acknowledge skilled technical assistance from Mrs $\mathbf{M}$. Franklin and support from the Wheat Industries Research Council of Australia and from Murdoch University special research funds.

\section{REFER ENCES}

AleF, K. \& Kleiner, D. (1982). Evidence for an ammonium transport system in the $\mathrm{N}_{2}$-fixing phototrophic bacterium Rhodospirillum rubrum. Archives of Microbiology 132, 79-81.
BARnes, E. M. \& Zimniak, P. (1981). Transport of ammonium and methylammonium ions by Azotobacter vinelandii. Journal of Bacteriology 146, 512516. 
Bellion, E. \& Weyland, L. (1982). Methylamine uptake in Pseudomonas species MA: utilization of methylamine as the sole nitrogen source. Journal of Bacteriology 149, 395-398.

Bellion, E., Ali Khan, M. Y. \& Romano, M. J. (1980). Transport of methylamine by Pseudomonas sp. MA. Journal of Bacteriology 142, 786-790.

Bergersen, F. J. \& Turner, G. L. (1967). Nitrogen fixation by the bacteroid fraction of breis of soybean root nodules. Biochimica et biophysica acta 141, 507 515

Bergersen, F. J. \& TURner, G. L. (1976). The role of $\mathrm{O}_{2}$ limitation in control of nitrogenase in continuous cultures of Rhizobium sp. Biochemical and Biophysical Research Communications 73, 524-531.

Bergersen, F. J. \& TuRner, G. L. (1978). Activity of nitrogenase and glutamine synthetase in relation to availability of oxygen in continuous cultures of cowpea Rhizobium sp. supplied with excess ammonium. Biochimica et biophysica acta 538, 406-416.

Brown, C. M. \& DilworTh, M. J. (1975). Ammonia assimilation by Rhizobium cultures and bacteroids. Journal of General Microbiology 86, 39-48.

DilworTH, M. J. \& GLENN, A. R. (1982). Movements of ammonia in Rhizobium leguminosarum. Journal of General Microbiology 128, 29-37.

DUGGLEBY, R. G. (1981). A nonlinear regression programme for small computers. Analytical Biochemistry 110, 9-18.

FAWCETT, J. K. \& SCOTT, J. E. (1960). A rapid and precise method for the determination of urea. Journal of Clinical Pathology 13, 156-159.

Glenn, A. R., Poole, P. S. \& Hudman, J. F. (1980). Succinate uptake by free-living and bacteroid forms of Rhizobium leguminosarum. Journal of General Microbiology 119, 267-271.

GlenN, A. R., ARwas, R., McKay, I. A. \& DilWORTH, M. J. (1984). Fructose metabolism in wildtype, fructokinase-negative and revertant strains of Rhizobium leguminosarum. Journal of General Microbiology 130, 231-237.

Gober, J. W. \& KashKet, E. R. (1983). Methylammonium uptake by Rhizobium sp. $32 \mathrm{H} 1$. Journal of Bacteriology 153, 1196-1201.

HartmanN, A. \& Kleiner, D. (1982). Ammonium (methylammonium) transport by Azospirillum spp. FEMS Microbiology Letters 15, 65-67.

Hudman, J. F. \& GlenN, A. R. (1980). Glucose uptake by free-living and bacteroid forms of Rhizobium leguminosarum. Archives of Microbiology 128, 72-77.

JoHNSTON, A. W. B. \& BERINGER, J. E. (1975). Identification of the Rhizobium strains in pea root nodules using genetic markers. Journal of General Microbiology 87, 343-350.

KLEINER, D. (1975). Ammonium uptake by nitrogen fixing bacteria. I. Azotobacter vinelandii. Archives of Microbiology 104, 163-169.

KLEINER, D. (1981). The transport of $\mathrm{NH}_{3}$ and $\mathrm{NH}_{4}^{+}$ across biological membranes. Biochimica et biophysica acta 639, 41-52.

KLEINER, D. (1982). Ammonium (methylammonium) transport by Klebsiella pneumoniae. Biochimica et biophysica acta $688,702-708$.

Kleiner, D. \& FitzKe, E. (1979). Evidence for ammonia translocation by Clostridium pasteurianum. Biochemical and Biophysical Research Communications 86, 211-217.

K LEINER, D. \& FitZKE, E. (1981). Some properties of a new electrogenic transport system: the ammonium (methylammonium) carrier from Clostridium pasteurianum. Biochimica et biophysica acta 641, 138147.

LaAne, C., Krone, W., Konings, W. \& Veeger, C. (1980). Short-term effect of ammonium chloride on nitrogen fixation by Azotobacter vinelandii and by bacteroids of Rhizobium leguminosarum. European Journal of Biochemistry 103, 39-46.

O'Gara, F. \& Shanmugam, K. T. (1976). Regulation of nitrogen fixation by rhizobia. Biochimica et biophysica acta 437, 313-321.

OSBURNE, M. A. (1982). Rhizobium meliloti mutants altered in ammonium utilization. Journal of Bacteriology 151, 1633-1636.

SPIES, J. R. (1957). Colorimetric procedures for amino acids. Methods in Enzymology 3, 467-477.

Stevenson, R. \& Silver, S. (1977). Methylammonium uptake by Escherichia coli: evidence for a bacterial $\mathrm{NH}_{4}^{+}$transport system. Biochemical and Biophysical Research Communications 75, 1133-1139.

TUBB, R. S. (1976). Regulation of nitrogen fixation in Rhizobium spp. Applied and Environmental Microbiology 32, 483-488.

WiEgel, J. \& KLEINER, D. (1982). Survey of ammonium (methyl-ammonium) transport by aerobic $\mathrm{N}_{2}$ fixing bacteria - the special case of Rhizobium FEMS Microbiology Letters 15, 61-63. 